\title{
Preparation Doped CuO Thin Film and Studies of Its Antibacterial Activity
}

\author{
A.H. Mustafa, M.M. Sadeer And S.A. Duha* \\ Department of Applied Science, University of Technology, Baghdad, Iraq
}

\begin{abstract}
In this work, $\mathrm{Mn}$ doped $\mathrm{CuO}$ thin films were prepared by using spray pyrolysis method. Different volume ratios of $\mathrm{Mn}(0 \%, 2 \%$, and $4 \%)$ were used to dope $\mathrm{CuO}$ in order to form $\mathrm{Mn}-\mathrm{CuO}$ thin films. These films were annealed in furnace at temperature $400{ }^{\circ} \mathrm{C}$ for $3 \mathrm{~h}$. The characteristics and structure of films were then examined using X-ray diffractometry and scanning electron microscopy analysis. The X-ray diffractometry pattern showed that all films were polycrystalline having anatase phase only, and the films with different doping ratio exhibited characteristic peaks of anatase crystal planes (111) and (111) at $35.6^{\circ}$ and $38.73^{\circ}$ direction, respectively. The scanning electron microscopy observation of the $\mathrm{CuO}$ film doped with $2 \% \mathrm{Mn}$ revealed a smoother surface compared to the other prepared films. The antibacterial properties of $\mathrm{Mn}$ doped $\mathrm{CuO}$ thin films showed the reduction in growth of $E$. coli and $S$. aureus which increased significantly at high concentration of Mn doping level (2\% and $4 \%$, respectively) as compared with undoped $\mathrm{CuO}$ with $0 \%$ concentration of $\mathrm{Mn}$ thin films.
\end{abstract}

DOI: 10.12693/APhysPolA.135.596

PACS/topics: spray pyrolysis method, $\mathrm{CuO}$, antibacterial properties of $\mathrm{CuO}$

\section{Introduction}

Thin films are layers of any material deposited over different substrates to improve and achieve new properties that give better applications for some materials. Recently, the use of thin films has become very extensive because it presents different properties and applications of $\mathrm{CuO}$ thin films has grown. These include the reactive sputtering, chemical vapour deposition (CVD), sol-gel, and thermal oxidation [1]. Among all these, spray pyrolysis technique has stoichiometry in multi-component system and splendid control of chemical uniformity. Cupric oxide $(\mathrm{CuO}$, tenorite) is a monoclinic $p$-type semiconductor with a narrow band gap of $1.2-1.5 \mathrm{eV}$ at room temperature with lattice parameter $a=4.6837 \AA, b=3.4226 \AA$, $c=5.1288 \AA$ and $\beta=99.54^{\circ}$ [2]. On account of their potential uses in many technological fields, copper oxide $(\mathrm{CuO})$ has been established as a number of applications like gas sensors, solar photo voltaics, and lithium ion electrodes, etc. [3]. Copper oxide, in its metal or ions forms, shows excellent antimicrobial activity against a number of microorganisms including bacteria, fungi, algae, and viruses, and yet is relatively safe for humans [4]. Only a few studies have reported a significant role of copper as bactericidal agent [5]. It shows a significantly higher bactericidal activity in comparison to bulk $\mathrm{CuO}$ microparticles. $\mathrm{CuO}$ structures were reported as potential antibacterial agents by other groups as well. Trapalis et al. [6] and Akhavan et al. [7] reported $\mathrm{CuO}-\mathrm{SiO}_{2}$ composite thin film and $\mathrm{CuO} / \mathrm{Cu}(\mathrm{OH})_{2}$ nanostructure, respectively, generated on copper foil as effective antibacterial against $E$. coli bacteria when the bacterial suspension

*corresponding author; e-mail: duhasaadi2015@gmail.com drop was tested on these surfaces. Perelshtein et al. [8] have reported antibacterial $\mathrm{CuO}$-cotton textile against E. coli and S. aureus. Gao et al. [9] reported strong antibacterial activity of $\mathrm{CuO}$ nanostructures comparable to established antibiotics as well as their photocatalytic potential. However, the growth of new resistant strains of bacteria and fungi has led to the searching of new bactericides and fungicides that can effectively reduce the harmful effects of microorganisms [4]. In this work thin films of $\mathrm{CuO}$ with different amount of $\mathrm{Mn}$ were successfully prepared via spray pyrolysis method and the structural properties were reported by X-ray diffraction (XRD) and scanning electron microscopy (SEM). In addition to the antibacterial activity, Mn-doped $\mathrm{CuO}$ thin films were also examined against E. coli and $S$. aureus.

\section{Experimental work}

\subsection{Preparation of thin films}

In this work, spray pyrolysis method is used to prepare $\mathrm{CuO}$ thin film with $0.1 \mathrm{M}$ of $\mathrm{CuCl}_{2} \cdot 2 \mathrm{H}_{2} \mathrm{O} .0 .1 \mathrm{M}$ of $\mathrm{MnCl}_{2} \cdot 4 \mathrm{H}_{2} \mathrm{O}$ aqueous solution was used to prepare $\mathrm{Mn}$ doped $\mathrm{CuO}$ with different volume ratios $(0 \%, 2 \%$, and $4 \%$ ). The resulting solutions were mixed by using a magnetic stirrer till the formation of dark blue and clear solutions, without any suspension of particles. Then, the films were sprayed onto glass substrates which was heated previously to $300 \pm 5{ }^{\circ} \mathrm{C}$, the carrier gas was a compressed air, and the solution flow rate was $\approx 3 \mathrm{ml} / \mathrm{min}$ while the gas flow rate was $30 \mathrm{l} / \mathrm{min}$. The distance between the nozzle and the substrates was kept at $25 \mathrm{~cm}$. The film thicknesses were measured by laser interference. This method is based on interference of the laser beam reflected from thin film surface and substrate. After deposition, the prepared films are annealed in furnace at temperature $400^{\circ} \mathrm{C}$ for $3 \mathrm{~h}$. To avoid excessive cooling of substrates, successive spraying process was used with 
time period of $3 \mathrm{~s}$ and then stoppage time of $30 \mathrm{~s}$ and so on. The crystalline structure of the deposited films was examined by using X-ray diffractometer (Shimadzu XRD - 7000) with $\mathrm{Cu} K \alpha$ radiation and the wavelength was $1.5406 \AA$.

\subsection{Antibacterial activity test}

The antibacterial activity of pure $\mathrm{CuO}$ and different amount of $\mathrm{Mn}$ doped-CuO thin films, respectively against the bacteria $E$. coli and $S$. aureus was studied using the antibacterial drop test [10]. Both bacteria samples were cultured in an $\mathrm{LB}$ medium at $37^{\circ} \mathrm{C}$ for $24 \mathrm{~h}$. The cultured bacteria samples were diluted to reach approximately the concentration of bacteria corresponding to the MacFarland scale $\left(10^{7} \mathrm{CFU} / \mathrm{ml}, \mathrm{CFU}\right.$ - colony forming units). As shown in Fig. 1, two groups of samples, each containing three thin coated films, prepared in different conditions of deposition method, were placed in sterilized Petri dishes. Then $100 \mu \mathrm{l}$ of bacterial suspension was added on each thin film. The samples were left at room temperature in sterilized hood and exposed to UV light for $5 \mathrm{~h}$ in the antibacterial test. After this time period the bacteria-containing drops were washed from the glass surfaces using $1 \mathrm{ml}$ of phosphate buffer solution (PBS). Then, $100 \mu \mathrm{l}$ of each bacteria suspension washing was dispersed on an nutrient (N.) agar culture medium. The numbers of colony bacteria in the Petri dishes were counted after incubation for $24 \mathrm{~h}$ at $37^{\circ} \mathrm{C}$.

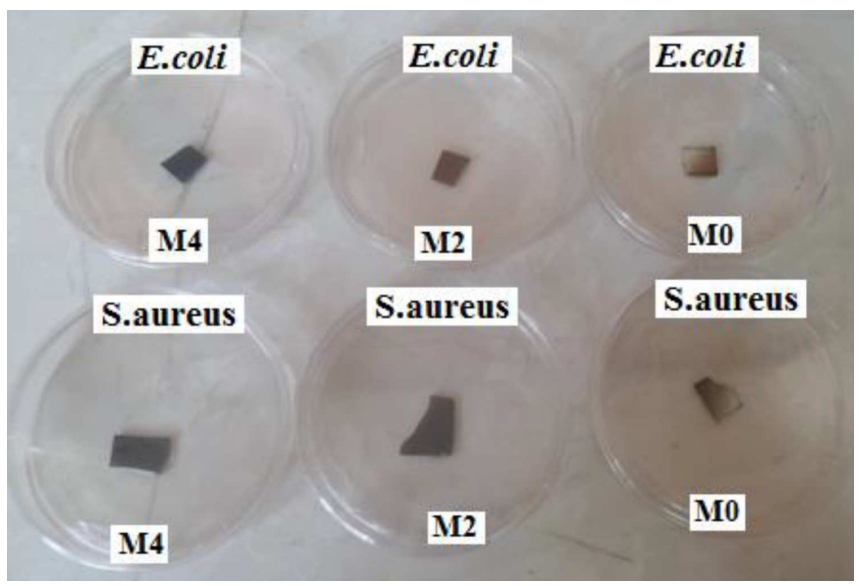

Fig. 1. Illustration of the antimicrobial test for the glass deposited with a thin film.

The antibacterial activities of films against $E$. coli and $S$. aureus bacteria can be obtained from survival rate of bacteria to estimate the precise value of $\mathrm{CFU}$ can be defined by a simple formula shown in Eq. (1) as follows $[11,12]$ :

$$
\text { survival rate }=(Y / X) \times 100 \% \text {, }
$$

where $X$ and $Y$ are the CFU before and after exposure, respectively.

\section{Results and discussion}

\subsection{XRD analysis}

The phase composition and the crystalline size of pure $\mathrm{CuO}$ and doping $\mathrm{CuO}$ samples were evaluated by XRD analysis. In Fig. 2 the XRD pattern presents pure $\mathrm{CuO}$ $(0 \%)$ and $\mathrm{CuO}$ doped with $2 \%$ and $4 \%$ of thin films of $\mathrm{Mn}$. It was found that all the films were of polycrystalline structures having anatase phase only. From diffraction patterns, it was observed that the films with different doping ratio exhibited characteristic peaks of anatase crystal planes $(\overline{111})$ and $(111)$ at $35.6^{\circ}$ and $38.73^{\circ}$ directions, respectively. These results comply with the standard $\mathrm{CuO}$ XRD data. The mean crystal size $D$ of the film was estimated from Scherrer's Eq. (2):

$$
D=\frac{0.94 \lambda}{\beta \cos \theta},
$$

where $\lambda$ is $\mathrm{X}$-ray wavelength, $\beta$ is angular line width of half maximum intensity, and $\theta$ is Bragg's angle.

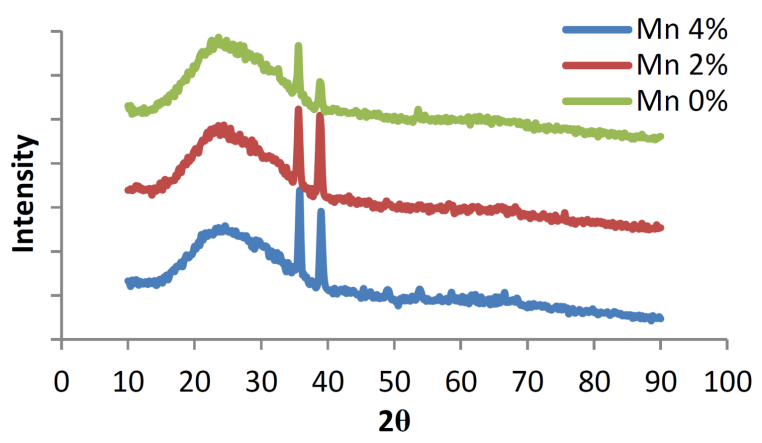

Fig. 2. X-ray diffraction pattern of pure $\mathrm{CuO} 0 \%$ and $\mathrm{CuO}$ doped with different content of $\mathrm{Mn} 2 \%$ and $4 \%$ thin films.

Doping ratios vs. crystallite sizes.

TABLE I

\begin{tabular}{c|c|c}
\hline \hline Doping ratio & $\begin{array}{c}(\overline{1} 11) \text { crystallite } \\
\text { size }[\mathrm{nm}]\end{array}$ & $\begin{array}{c}(111) \text { crystallite } \\
\text { size }[\mathrm{nm}]\end{array}$ \\
\hline $0 \%$ & 24.3 & 16.4 \\
$2 \%$ & 17.26 & 17.63 \\
$4 \%$ & 20.18 & 18.56
\end{tabular}

The value of mean crystal size was in the range of 16-24 nm and it changed slightly with high concentration. The (111) peak intensity increased a little as the doping ratio increased. Therefore, there was an increase in crystal size, while the lowest crystal size appeared when doping with $2 \% \mathrm{Mn}$ for the peak (111). Table I shows the crystal size of the prepared thin films.

\subsection{SEM morphology study}

Figure 3 shows SEM images of pure $\mathrm{CuO}$ and doped $\mathrm{CuO}$ with various content of $\mathrm{Mn}(0 \%, 2 \%$, and $4 \%)$, respectively. It is clear that the particles have a semispherical shape with different sizes. From the results, the $\mathrm{CuO}$ film doped with $2 \% \mathrm{Mn}$ illustrates a smoother surface compared with the other films. 

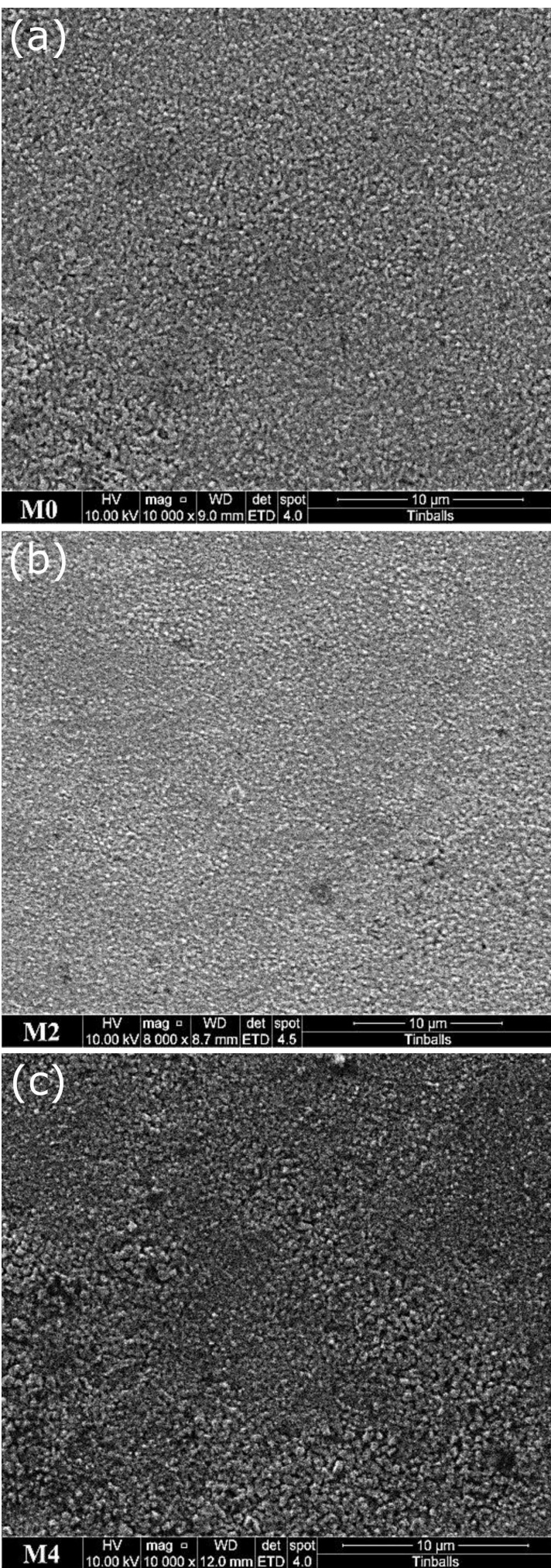

Fig. 3. SEM images of $\mathrm{CuO}$ thin films with different doping ratio of Mn: (a) $0 \%$, (b) $2 \%$, and (c) $4 \%$.

This has concluded from the XRD peaks as shown in Fig. 2, where the crystallite sizes presented the same recorded values for the crystallographic planes (111) and (111).

\subsection{The antibacterial activity of thin films}

The antibacterial activity of pure $\mathrm{CuO}$ and doped $\mathrm{CuO}$ with various content of $\mathrm{Mn}$ against Gram negative (E. coli) and Gram positive (S. aureus) bacteria were examined by the drop test. The results are shown in Figs. 4 and 5 , respectively.

The growth inhibition ability of $\mathrm{CuO}$ thin films against $E$. coli and $S$. aureus was observed to increase significantly with increase in the Mn doping level (2\% and $4 \%$, respectively).

The results reveal that the high concentration of $\mathrm{Mn}$ doped $\mathrm{CuO} 2 \%$ and $4 \%$ thin films, respectively, inhibited $100 \%$ growth of E. coli and S. aureus completely,

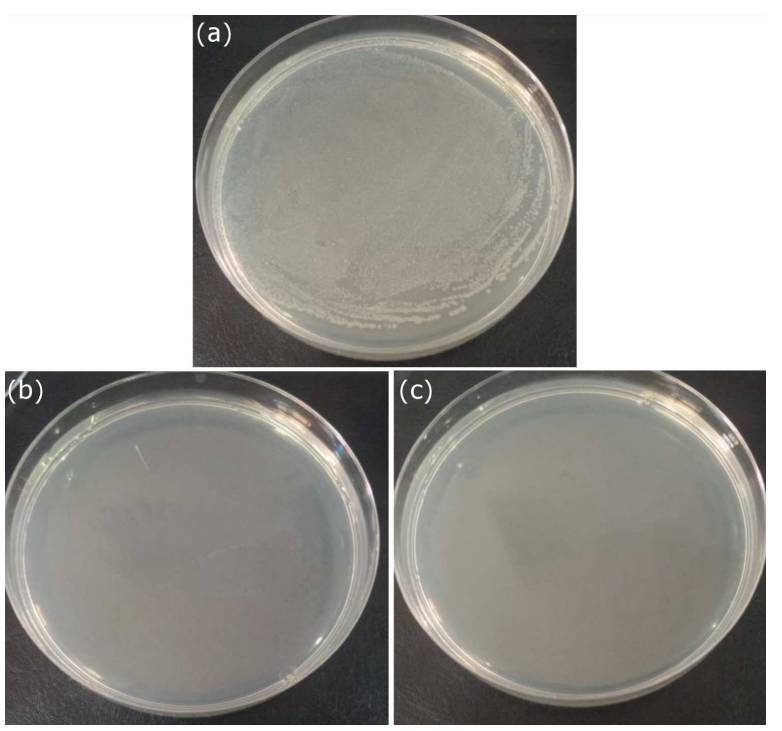

Fig. 4. Photographs of thin films samples against E. coli after incubation for $24 \mathrm{~h}$ at $37^{\circ} \mathrm{C}$ : (a) E. coli exposed to $\mathrm{M}_{0}(0 \%) \mathrm{Mn}$, (b) E. coli exposed to $\mathrm{M}_{2}(2 \%)$ $\mathrm{Mn}$, and (c) E. coli exposed to $\mathrm{M}_{4}(4 \%) \mathrm{Mn}$.

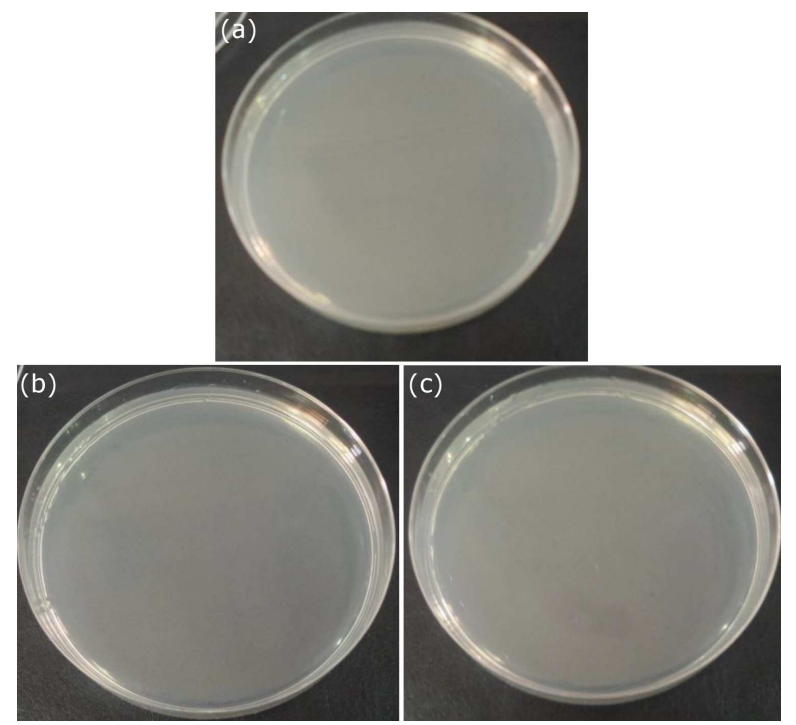

Fig. 5. As in Fig. 4, but for S. aureus bacteria. 

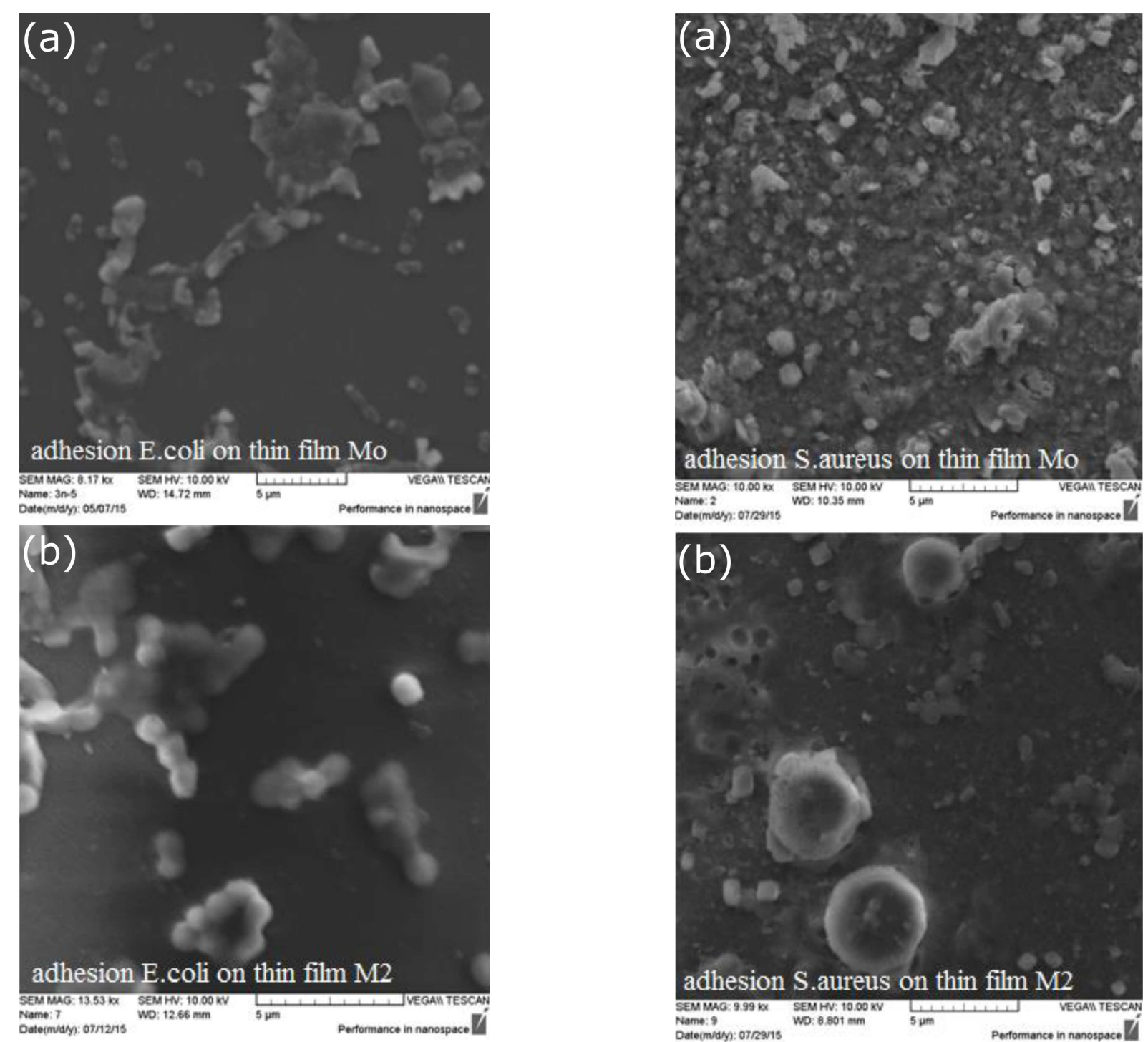

$$
\text { Dotolimasy: ornasns }
$$
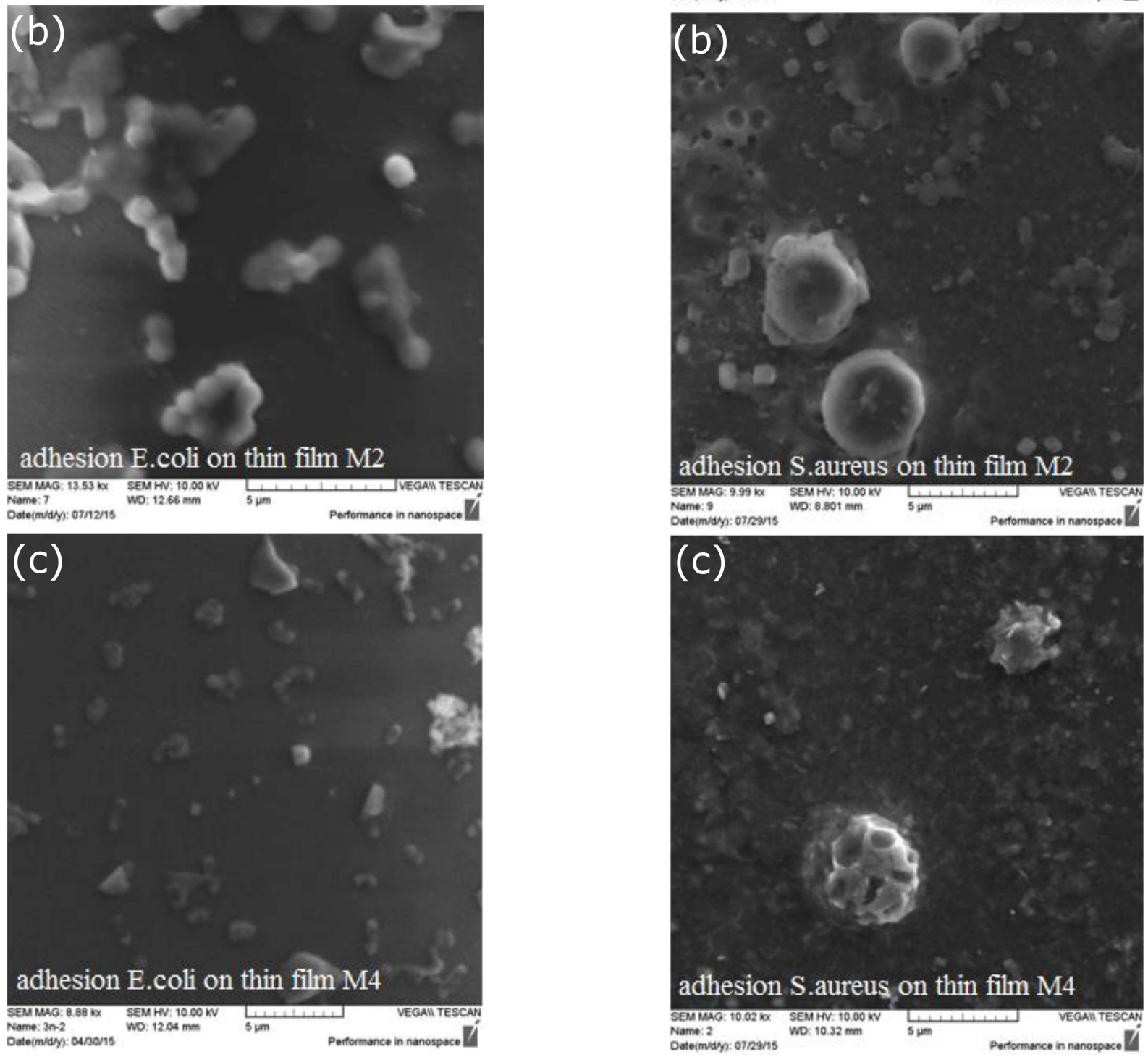

Fig. 6. SEM images of attaching E. coli bacteria on thin films samples during the exposition to UV light for $10 \mathrm{~h}$ : (a) $\mathrm{M}_{0}$, (b) $\mathrm{M}_{2}$, and (c) $\mathrm{M}_{4}$.

Fig. 7. As in Fig. 6, but for S. aureus. 
after $10 \mathrm{~h}$ of exposed to UV light in the antibacterial test as shown in Fig. 4b and c and Fig. 5b and c, while pure $\mathrm{CuO}(0 \%)$ is found to be more effective against $S$. aureus compared with $E$. coli as shown in Fig. 4a and Fig. 5a, respectively. Since the antibacterial activity of $\mathrm{CuO}$ thin film is increased with the increasing $\mathrm{Mn}$ dopant concentration. Moreover, this enhanced antibacterial behavior is expected, because of reactive oxygen species (ROS) generated including $\mathrm{OH}$ groups by single-electron reduction which does not require UV irradiation [13, 14]. However, photocatalysis using UV illuminated induced oxygen in bacterial cells. Since it has been generally accepted that possible mechanism of antibacterial photoactivity of metal oxides is due to interaction with highly reactive oxygen species (ROS) which would result in oxidative damage of the cell membrane or inside the cells as demonstrate with $E$. coli and $S$. aureus with $\mathrm{M}_{2}$ and $\mathrm{M}_{4}$ of high percentage doping of $\mathrm{Mn}$ concentrations.

\subsection{SEM of bacteria morphology}

The SEM images demonstrate the adhesion of Grampositive and Gram-negative organism's on three types of thin films samples $\mathrm{M}_{0}(0 \%), \mathrm{M}_{2}(2 \%), \mathrm{M}_{4}(4 \%)$ through the exposure to UV light for $10 \mathrm{~h}$ as illustrated in Figs. 6 and 7 , respectively.

The possible reason of the current result is due to the ROS generation including $\mathrm{OH}$ groups during photocatalysis using UV illumination which makes the rough surface of $\mathrm{Mn}$ doping $\mathrm{CuO}$ thin films very smooth and suitable for attachment to the cells. This demonstrates that thin films $\left(\mathrm{M}_{2}\right.$ and $\left.\mathrm{M}_{4}\right)$ possess high antibacterial properties as compared with $\mathrm{M}_{0}$ thin film. Since the roughness profile indicates an increase in particle height with Mn doping incorporation, the surface of films become rougher.

\section{Conclusions}

Spray pyrolysis method was used to prepare $\mathrm{CuO}$ thin film with $\mathrm{Mn}$ doped $\mathrm{CuO}$ with different volume ratios $(0 \%, 2 \%$, and $4 \%)$. The structural, morphological, and antibacterial properties were studied as a function of $\mathrm{Mn}$ dopant concentrations. From the results of XRD and SEM analysis, $\mathrm{CuO}$ film doped with $2 \% \mathrm{Mn}$ illustrated a smoother surface compared with the other films. High concentration of $\mathrm{Mn}$ doped $\mathrm{CuO}$ thin films revealed high antibacterial activity against $E$. coli and $S$. aureus, after $24 \mathrm{~h}$. The SEM images demonstrate the adhesion of Gram-positive and Gram-negative organism's on three types of thin films samples due to ROS generation including $\mathrm{OH}$ groups during photocatalysis using UV illumination which makes the rough surface of Mn doping $\mathrm{CuO}$ thin films very smooth and suitable for attachment to the cells.

\section{Acknowledgments}

The authors are thankful to the Center of Nanotechnology and Advanced Material, University of Technology, Baghdad, Iraq for helping and performing TEM analysis Day Petronic Co., (Tehran, Iran) and XRD (6000Shimadzu). Also, the authors are thankful to the Applied Science Department, University of Technology in Iraq, for performing SEM analysis.

\section{References}

[1] A.A. Ogwu, E. Bouquerel, O. Ademosu, S. Moh, E. Crossan, F. Placido, J. Phys. D Appl. Phys. 38, $266(2005)$.

[2] D. Wu, Q. Zhang, M. Tao, Phys. Rev. B 73, 235206 (2006).

[3] S.C. Ray, Solar En. Mater. Solar Cells 68, 307 (2001).

[4] G. Borkow, J. Gabbay, Curr. Med. Chem. 12, 2163 (2005).

[5] N. Cioffi, L. Torsi, N. Ditaranto, G. Tantillo, L. Ghibelli, L. Sabbatini, T. Bleve-Zacheo, M. D'Alessio, P.G. Zambonin, E. Traversa, Chem. Mater. 17, 5255 (2005).

[6] C.C. Trapalis, M. Kokkoris, G. Perdikakis, G. Kordas, J. Sol-Gel Sci. Technol. 26, 1213 (2003).

[7] O. Akhavan, R. Azimirad, S. Safa, E. Hasani, J. Mater. Chem. 21, 9634 (2011).

[8] I. Perelshtein, G. Applerot, N. Perkas, E. Wehourschuetz-Sigl, A. Hasmann, G. Guebitz, A. Gedanken, Surf. Coat. Technol. 204, 54 (2009).

[9] F. Gao, H. Pang, S. Xu, Q. Lu, Chem. Commun., 3571 (2009).

[10] C.C. Trapalis, J. Sol-Gel Sci. Technol. 26, 1213 (2003).

[11] K.J. Shieh, M. Li, Y.H. Lee, S.D. Sheu, Y.T. Liu, Y.C. Wang, Nanomedicine 2, 121 (2006).

[12] K. Hideki, K. Akihiko, J. Phys. Chem. B 1065029 (2002).

[13] P. Madah, N. Shahtahmasebi, A. Kompany, M. Mashreghi, M.M. Bagheri-Mohagheghi, A. Hosseini, Phys. Scr. 84, 5 (2011).

[14] S.Q. Sun, B. Sun, W. Zhang, D. Wang, Bull. Mater. Sci. 31, 61 (2008). 